\title{
Reflection of national and cultural specifics in the text of advertising (on material of texts of advertising of the Chinese and Russian building companies)
}

\author{
Stanislav $\mathrm{Li}^{1, *}$, Lyudmila Araeva ${ }^{1}$, and Guo $\mathrm{Xin}^{2}$ \\ ${ }^{1}$ Kemerovo State University, 650000, Krasnaya str., 6, Kemerovo, Russia \\ ${ }^{2}$ Qiqihar University, 161006, Wenhua str., 42, Heilongjiang, China
}

\begin{abstract}
The purpose of article is detection of the general and specific advertising texts of real estate development companies in slogans in the Russian and Chinese languages. Any advertising is designed for the consumer who will buy the advertised goods. The scientific novelty of the study is determined by the fact that for the first time a propositional analysis of the "advertisement" frame in Chinese, which is an isolating one, is carried out. This approach is based on the technique of frame modeling, where the main components are the deep structures of knowledge - propositional schemes and verbal - propositions. Advertising efficiency is caused by the accounting of the traditions which developed in a certain nation, stereotypes and those associations which invisibly are present at texts. The phraseological units functioning in this or that culture are created on the basis of these traditions, cultural stereotypes; reflect features of a world view of the nation. The conducted research allows revealing that at the heart of phraseological units there are same propositional structures which are invisibly sending a thought of the person to propositions. The person learns the world, comparing one to another. It is propositional organized phraseological units allow to reveal the associations, general and unique for the nation. On the one hand, to understand that, at the most abstract level all languages are arranged equally what Humboldt wrote about, and, with another - to see an originality of each language.
\end{abstract}

\section{Introduction}

Today, the life of modern society cannot be imagined without advertising. Advertising surrounds us everywhere: at home, on the street, in public transport, at work. The advertising text has a significant influence on the formation of values and patterns of behavior in society. Currently, advertising is not only the dissemination of commercial information about a

\footnotetext{
*Corresponding author: li.stanislav999@ yandex.ru
} 
product or service; it is an instrument through which one can influence the socio-cultural, educational and aesthetic spheres [5].

\section{Problem Statement}

Comparison of two structurally different languages (Russian and Chinese) in the cognitivecultural aspect is an actual task for modern linguistics. The study of the language of advertising attracts linguists' interest, since it has not only its own linguistic features, but also includes national-specific components and, consequently, participates in the formation of national stereotypes representing the mentality of a particular people. We can say that advertising not only demonstrates new products and services, but also reflects the current state of the national culture, is the transformation of cultural stereotypes, values and patterns of behavior that function in modern society [8].

On the one hand, the cognitive-cultural approach in the study of advertising texts allows to analyze purely linguistic features, and on the other hand, to reveal its nationally specific features.

\section{Research Questions}

The purpose of this study is a cognitive-cultural analysis of advertising communications of Chinese and Russian construction companies and, as a result, the identification of universal language characteristics and national-specific features.

The materials for the analysis are texts of Russian and Chinese advertising of construction companies. The unit of research is the advertising slogan. The advertising slogan is a short and concise expression, which formulates the essence of the advertising message. Through advertising slogan there is a suggestive effect on the human psyche, in other words, social manipulation. This impact on human carried out in order to form a certain pattern of behavior, changes in thinking processes. That is, a person does not think about acquiring any product, but under the influence of the advertising slogan he starts to imagine how his housing will change, how comfortable it will be for him. Involuntarily there are associations related to how the repair is done by neighbors and friends [6].

\section{Purpose of the Study}

In the study of the material, the method of propositional and frame modeling, the descriptive method, the method of continuous sampling, the method of free associative psycholinguistic experiment, comparative-comparative analysis of practical material, and the method of introspection were used.

\section{Research Methods}

One of the main features of the phraseology of the Chinese language is the phraseological units 成语 chéng yŭ, from Chinese translates as "ready expressions". "Chengyu" is set phrases, which the Chinese use in oral and written speech, they, as a rule, consist of four hieroglyphs.

Chinese advertising slogan in its form resembles "paired inscriptions", rhymed couplets, which in ancient China praised the actions of their ancestors. Chinese slogan, as a rule, consists of two phrases of four characters. They can include chengyu or its individual elements. 
Let's provide some examples:

- 大气合成, 王者风范dàqì héchéng, wángzhě fēngfàn (the atmosphere of harmony, the standard of the emperor).

In this slogan, the second part 王者风范 wángzhě fēngfàn (the emperor's standard) is a chengyu-type phraseology. For the Chinese people their social status is very important, and its criterion is the presence of an expensive car, elite real estate, etc.

- 臻贵礼遇, 缘定今生zhēn guì lùyù, yuán dìng jīnshēng (to be worthy of a courteous reception, destiny is predetermined by a golden life).

This slogan uses the phraseology 缘定今生 yuán dìng jīnshēng, which can be translated as "fate predetermines the real life", but this chengyu is transformed, namely, the third element was replaced: the hieroglyph 今 jīn (this) was changed to 金 jīn (gold). Thus, the slogan 缘定金生 yuán dìng jīnshēng can be translated as: “destiny is predetermined by the golden life", this means that the company is engaged in the sale of elite real estate. That is, the slogan is oriented to those traditions that exist in the ordinary consciousness of the Chinese.

- 最迟上学, 最早到校zuì chí shàngxué, zuìzăo zăodàoxiào (later all leave the house and go to school, the first student to come to school).

This slogan is also constructed on the chengyu type; it has eight hieroglyphs in its composition. Target audience is parents with children of school age. In China, it is possible to identify a child in school only at the place of residence, so residential complexes, where there is a good school nearby, are very much appreciated.

- 天赋黄金, 求之若渴Tiān fù huángjīn, qiú zhī ruò kě (golden skyscrapers, feel thirsty for them).

Chenggyu 求之若渴qiú zhī ruò kě translates as “feeling thirst for knowledge". In this slogan the element 知 zhī (knowledge) was replaced by 之 zhī (3 person pronoun in the book language). The addressee translates this slogan so: golden skyscrapers, feel for them (golden skyscrapers, that is, to knowledge) thirst.

- 唯此山河, 一生独赏wéi cǐshānhé ȳ̄shēng dú shăng (only here there are mountains and rivers, enjoy all my life). This slogan informs the addressee that this property is located in a picturesque place.

Thus, Chinese slogans have the following characteristics:

1. Use in its composition of phraseological units on the Chengyu type;

2. Symmetry is the ethno cultural feature of the Chinese, the desire for pairing, which manifests itself in language, literature, architecture, etc.;

3. Optimal number of syllables for describing a brief but at the same time complete and clear characteristics of an object or phenomenon;

4. Use of the writing-book language of Wenyang to create an impression of the attribution of the text to a work of high style;

5. The Chinese slogan resembles the structure of paired inscriptions 对联 (duilián);

6. The Chinese slogans are based on Chinese traditions: to live in a rich house, in a picturesque place, next to an elite school.

The use of Chengyu in the texts of advertising makes it imaginative, allows you to more effectively influence the consciousness of a person, arouse interest in a product or service, and induce to action, to purchase the advertised product. Native speakers associate advertising text based on Chengyu, with a work of high style. The advertising slogan 
provokes the associations connected with the settled traditional representations about comfort of habitation of the Chinese family.

In the texts of Russian advertising there is also a phenomenon of phraseologization, in most cases phraseological units are used in an incriminating way. That is, their transformation takes place: adding or omitting some components, replacing lexical units, etc. This in the advertising text serves as a stylistic device, thanks to which the information embedded in the text of the advertisement has a pragmatic effect. According Tretyakova, "Phraseological units can undergo transformations with various communicative purposes: clarify the meaning, specify the phraseology regarding the language situation, express subjective appraisal" [9]. Phraseological units are bright, emotionally colored turns belonging to a certain speech style and reflecting the picture of the people's world [1]. In other words, phraseological units are original codes of culture, traditions of the nation, organically included in the everyday consciousness of the people. Frozen formulas, which, in the words of Humboldt [4], are newly born in speech, absorbing new traditions, but at the same time, the connection with the original phraseology is maintained, which is facilitated by the similarity of formal construction. Involuntarily there is an association with the change of hieroglyphs. The old hieroglyphs have not left the long-term memory of the Chinese, associations that have not been studied, are not represented in dictionaries, have been preserved, but are used in the everyday speech of the Chinese, making specific background knowledge that shows the specificity of the internal form of the Chinese language.

Modifications in the Russian advertising slogan allow also seeing the connectedness of the original phraseology with the modern one.

- "I came, I saw and I stayed." In this example, the transformation of the winged expression "Come, saw, conquered", often quoted in Latin "Veni, vidi, vici", is carried out by changing the composition of the composition while preserving the syntactic form, so the addressee can easily find out the winged expression in it.

- "APARTMENTS are the most juicy!"

Phraseology "in the juice." So you can say about a man in the prime of life.

- "Have children grown?"

- "Has the son grown?"

In these advertising texts, the hint of housing acquisition is not explicitly expressed. But when a person perceives certain thought pattern works, in other words, a stereotype of thinking.

The theory of stereotypes began to form in 1922 after the publication of the book "Public Opinion" by the American sociologist, writer and journalist Walter Lippman. According to Lippmann's conception, the "stereotype" is a simplified, preconceived notion of objects and phenomena of reality that does not follow from one's own experience, but arises on the basis of mediated perception [7]. Sociologist A. V. Merenkov considers stereotypes as a "program", which is a kind of guide to action in the interaction of a person with the surrounding reality [8]. In Russian society, a stereotype emerged: adult children should not live together with their parents, so parents buy a separate apartment for their children. In the advertising texts "Have children grown?", "Has the son grown?" Implicitly laid a hint: "Your children have grown, it's time to buy a separate apartment for them."

Among the advertisers, the term "typical representative of the target audience" is popular. The target audience of this advertising communication is parents who have adult children.

The psychologist, the creator of the "theory of the orientation" Uznadze writes, "... there is nothing more characteristic of a person than the fact that the reality surrounding him affects him in two ways - either directly, by sending him a series of stimuli directly acting on him, or indirectly, through verbal symbols that, without themselves having their own independent 
content, only present to us this or that irritation" [11]. Thus, the questions "Have children grown?", "Has son grown?" are irritants for the target audience. The person receiving this information correlates it with the previously established stereotypes and draws certain conclusions on the basis of them.

- "They say that there is a lot of water in our advertising. It's true"

The word "water" in modern Russian is often used in the sense of "superfluous information".

In this advertising communication, the emphasis is on its non-verbal component. On the advertising signboard there is a house on the bank of the reservoir. The phrase "a lot of water" is perceived by the addressee not as "the presence of unnecessary information", but indicates that the house is located next to the pond. This language game gives the message a great expressive power.

\section{Findings}

Chinese and Russian advertising slogans are propositional structured. This makes it possible to consider them as hierarchically organized structures of knowledge, as a way and space for storing information contained in the derived word in the advertising text.

Propositional structures in Chinese advertising:

1. Place in relation to the place of another subject: "The atmosphere of harmony, the standard of the emperor." The proposition: "The place is the same as that of the emperor." The emperor for the Chinese is a symbol of power and material well-being.

2. Place in relation to the place and the subject: "Later all leave the house and go to school, the first student to come to school." The place in the proposition is formally expressed - the school, the subject is not explicitly expressed, but from the proposition and the non-verbal component we understand that this is a schoolboy.

3. Place in relation to another place: "Only here there are mountains and rivers, enjoy all my life." The environmental situation in China is currently very heavy, therefore the property next to the reservoirs in ecologically clean areas is highly valued. This attracting factor is used by advertisers in this slogan.

4. Place in its qualitative description: "Golden skyscrapers, feel thirsty for them". Gold is a symbol of wisdom, earthly goods and prosperity. "Since color perception of words is impossible to express, our visual categories we associate with the samples available to man. Such samples are noble metals, plants, animals and other models that play an important role in human life" $[2,3]$.

5. Place by the result: "To be worthy of a courteous reception, destiny is predetermined by a golden life". From this slogan you can deduce the meaning: get this property, and your life will be guaranteed to be successful.

In Russian advertising the following propositional structures are realized:

1. Place in relation to the subject: "Have children grown?"; "Has the son grown?" The subjects of this structure are the son and daughter. This reflects the habitual desire for the Russian people to provide decent housing for their children.

2. Place in relation to another place: "They say that there is a lot of water in our advertising. It's true". Proposition: the property is located by the pond.

3. A place in relation to its qualitative characteristic: "APARTMENTS are the most juice!" = The best apartments.

Thus, the Russian person's association with the house is somewhat different than for the Chinese. There is no excessive comfort; there is no association with gold. Strangely enough, in Russian advertising there is no indication of finding an elite school near the house. But at the same time there are intersections. For the Chinese is a very picturesque place in which 
the house is under construction, for the Russian this fact is also significant. But in this case there is a stylistic device built on the antithesis: water as the location of the house and water as something empty, used, including for deception. For Chinese and Russian, the quality of the acquired property is significant: apartments - the most juice, golden apartments.

The common characteristic of Chinese and Russian outdoor advertising is the use of phraseological units, the semantic completeness, with external simplicity, is created by attracting the idiomatic background of Chinese and Russian languages, which undoubtedly has a pragmatic goal, namely, rendering emotional and intellectual impact on the recipient, because Idiomatic texts, oriented to background, stereotypically fixed in the ordinary consciousness of the speakers of the association language, easily find the way to his consciousness.

Propositional structures are at the basis of the speech activity of representatives of modern civilization, including Chinese and Russian, at a deep level [2]. They are realized in the language in the form of falsified judgments, propositions. Phraseological units are no exception. Propositionally organized semantics of phraseological units shows the features of the worldview of the Russian and Chinese nation, the national linguistic view of the world.

The propositions realized within the propositional structures create a whole frame, within which there are background knowledge, conditioned by the mentality and culture of the nation. The idiomatic nature of the semantics of phraseological units is supported by a whole complex of associations that are familiar to Chinese and Russian. Some of them are formally represented in the propositions, others are off-screen. Idiomaticity in advertising is a kind of key that opens the door for the native speaker to the stereotypical situations that have developed in society (the desire to provide their children with housing, expensive real estate is an indicator of high social status, etc.), prompting him to take certain actions, in this case Is the purchase of real estate.

Thus, we can draw the following conclusion. Representatives of different nationalities in the basis of the text (in our case, this is advertising) are the same propositional structures of knowledge that are explicated in the language by propositions. In these propositions, along with the formally presented meanings, background knowledge preserving the specifics of the associative background of a particular people is preserved.

\section{Conclusion}

The research was conducted with the support of the Russian Foundation for Humanities. Project No. 17-04-00253.

\section{References}

1. N. F. Alefirenko, Phraseology in the light of modern linguistic paradigms (ELPPIS, Moscow, 2008)

2. L. A. Araeva, S.I. Li, Vestnik of the Kemerovo State University of Culture and Arts, 27 (2014)

3. L. A. Araeva, S.I. Li, A propositional analysis of the color categories in Chinese, Russian, English and Teleut languages: general-theoretical and typological problems of linguistics (Altai State Academy of Education named after V.M. Shukshin, Barnaul, 2014)

4. V. Humboldt, Selected works on linguistics (Progress, Moscow, 1984)

5. N. O. Dolgikh, Bulletin of Perm University, 4 (2009) 
6. T. S. Dobrikova, Young Scientist, 12 (2012)

7. U. Lippman, Public opinion (Institute of the Public Opinion Foundation, Moscow, 2004)

8. A. V. Merenkov, Sociology of stereotypes (Publishing House of the Ural University, Ekaterinburg, 2001)

9. I. Yu. Tretyakova, Occasional transformations of phraseological units with the "soul" component: phraseologism and the word in the national-cultural discourse (linguistic method) (Elpis Publishing House, 2008)

10. A. Bogoviz, S. Lobova, Y. Ragulina, A. Alekseev, V. Garnova, MediaobrazovanieMedia Education, 3, 7-14 (2017)

11. D. N. Uznadze, Psychology of the orientation (Meaning, St. Petersburg, 2001) 